\title{
Can Functional Cell Models Replace Laboratory Animals in Biomedical Research?
}

\section{Avrelija Cencic*}

University of Maribor Slovenia, Europe

Laboratory animals are still used and abused in most of the areas of biomedical research worldwide. In spite of the fact that accurate numbers are difficult to obtain, the British Union for the Abolition of Vivisection (BUAV) estimates that 100 million vertebrates are experimented on around the world every year, 10-11 million of them in the European Union. The total number of animals used for experimental and other scientific purposes in 2008 (with one Member State reporting for 2007) is just above 12, 0 million. Rodents together with rabbits represent more than $80 \%$ of the total number of animals used in the EU. Mice are the most commonly used animal accounting for $59 \%$ of the total use, followed by rats at $17 \%$. As stated in the fourth and fifth statistical reports no Great Apes were used for scientific purposes in the EU in 2008.

The improvements in public health and safety made possible through the use of animals in research and testing are well known. But these questions remain" Do these advances justify animal use? How much of the improvements were actually dependent on the use of animals?

The animal models, if ever, give scientifically appropriate and relevant results for human, due to obvious species-specific differences in anatomy, biochemistry, physiology, pharmacokinetics, and toxic responses. Epecially in medicine and pharmacy the "safety testing" on animals led to thousands of deaths worldwide, due to the evidence that animal tests are not only worthless, but they are also dangerously unpredictable. Use of replacement alternative methods, especially incorporating human cells and tissues, avoids such confounding variables.

As Dr. Fadali stated in his book of "Animal Experimentation - a harvest of shame 'Animal models differ from their human counterparts. Conclusions drawn from animal research, when applied to human disease are likely to delay progress, mislead and do harm to the patient' 'The claim that we owe most, if not all of our advances in medicine to animal research is not only untrue, but also preposterous and absurd an outright lie'.

The scientific and political attempts to find alternatives to animal use in biomedicine started early in 20th century in the USA as well as in Europe, that finally resulted in the three $\mathrm{R}$ regulation that have been introduced into European legislation (OJ L136 of 08.06.2000):

Reduction: Alternatives: methods for obtaining comparable levels of information from the use of fewer animals in scientific procedure, or for obtaining more information from the same number of animals.

Refinement: alternatives: methods which alleviate or minimise potential pain, suffering and distress, and which enhance animal wellbeing.

Replacement: alternatives: methods which permit a given purpose to be achieved without conducting experiments or other scientific procedures on animals.
Being aware of the complex interactions in the subtle environment inside the body makes it clear that to find an appropriate alternative cell experimental model is not an easy accomplishment. It is essential, that invitro cell models provided, have satisfied two basic requirements: availability and easy handling for high-throughput testing and retention of tissue characteristics to support interpretation of results for the in vivo situation. Moreover, functional cell models defined as in vitro cell models, mimic in vivo situation and allow us to correlate these results with those we can get with animal experiments.

Up to date, numerous cell models have been employed for the studies in biomedical research: like cellular models of primary cell lines, virus immortalized cell lines, cancer cell lines, tissues and organ explants. Most widely utilized cell cultures in food toxicology are carcinogenic or transformed cell lines like Caco-2 and HT-29. They are valuable in the study of carcinogenic processes but cannot be used to mimic a healthy environment. Despite their human origin they have a phenotype and glycosylation distinct from normal gut epithelia $[1,2]$ and therefore they do not provide much advantage over animal models. The wide utilization of carcinogenic/transformed cell lines can probably be attributed to the fact that carcinogenic cell lines can be maintained very easily and were also the first to be stable through higher passages.

Cell lines differing, either due to transformation or inappropriate origin, from the targeting organ may have altered glycosilation, be unresponsive, or show metabolic and morphological changes. It is therefore necessary to choose cell lines with phenotypes as close as possible to the In vivo target [4]. At the same time, cells may behave differently when cultivated in an isolated environment missing cellcell interaction and chemical cross talk [2]. Cultivating cell lines in coculture or $3 \mathrm{D}$ models can overcome this problem by combining relevant cell lines such as intestinal epithelial cells with GALT macrophages.

For example, when scientist claim positive health benefits of e.g. nutraceuticals, which were obtained in Caco-2, the results are usually wrong, due to the fact that first of all, main absorbtion happens in the small intestine, while Caco-2 are the cancer cells of colon adenocarcinoma and the message they give is that when you eat this nutraceutical, your colon cancer will grow better.

*Corresponding author: Avrelija Cencic, University of Maribor Slovenia, Europe, Tel: + 386 23209028; E-mail: avrelija.cencic@uni-mb.si

Received April 18, 2012; Accepted April 20, 2012; Published April 23, 2012

Citation: Cencic A (2012) Can Functional Cell Models Replace Laboratory Animals in Biomedical Research? J Bioanal Biomed 4: e105. doi:10.4172/1948593X.1000e105

Copyright: (C) 2012 Cencic A. This is an open-access article distributed under the terms of the Creative Commons Attribution License, which permits unrestricted use, distribution, and reproduction in any medium, provided the original author and source are credited. 
Therefore, a consideration of a proper and relevant cell model is of essential importance for the right interpretation of research results. Now a days, a wide range of the normal cell lines from various animal and human tissues are established and available to scientifc community by cell culture collections and small biotech enterprises to enable the scientific community to perform the research accurately.

When designing a study and choosing the right cell model it is essential to address the following major concerns:

- Which cell line has the most relevant phenotype for a designed study?

- Which other organ systems have an influence In vivo on our employed system and how can we integrate them in our study?

- Is the model validated and if not, which validated model will be used as comparative control?

Functional cell models of normal, non-cancerogenic tissue have been successfully used in studies of transepithelial physiology of epithelia, epithelial crossing and biological activity of biomolecules mimicking uterine events [8,9]. Moreover, several functional small intestinal models of farm animals were developed to enable studies of interactions between foodborne pathogens, probiotic or protective cultures and the host. These models have been shown to be used as good models for gut research and were validated in vivo $[1,3,7,11,12,14,16]$ The muscle cell models, that have been used in nutrition, obesity and regenerative medicine research were proven accurate and efficient with validation intervention and clinical trials in human $[1,7]$

To conclude, the scientific facts in biomedical research have clearly proven that the proper functional cell models can replace the unnecessary use of laboratory animals. Despite the fact that such models lack the complexity of animal models, they have several advantages such as reproducibility of results, controlled environment, and in-depth mechanistic insight. With the development of new technologies and cultivation techniques, the identification of various bio markers will be possible, enabling establishment of reliable prediction models. But it is also a duty of scientists to enlighten the authorities, as especially for pharmaceutical industry, a lot of them are still using animals in spite of the fact they aknowledge their uselessness, but the use of animals is justified by the legal authorities demands for new drug approvals.

\section{References}

1. Nissen L, Chingwaru W, Sgorbati B, Biavati B, Cencic A (2009) Gut health promoting activity of new putative probiotic/protective Lactobacillus spp. strains: a functional study in the small intestinal cell model. Int J Food Microbiol 135: 288-294.

2. Cencic A, Langerholc $T$ (2010) Functional cell models of the gut and their applications in food microbiology-a review. Int J Food Microbiol 141: 4-14.

3. Langerholc T, Maragkoudakis PA, Wollgast J, Gradisnik L, Cencic A (2011) Novel and established intestinal cell line models - An indispensable tool in food science and nutrition. Trends Food Sci Tech 22: 11-20.

4. Peracaula R, Barrabés S, Sarrats A, Rudd PM, de Llorens R (2008) Altered glycosylation in tumours focused to cancer diagnosis. Dis Markers 25: 207-218.

5. Ivec M, Botic T, Koren S, Pauline MR, Rafael DL, et al. (2007) Interactions of macrophages with probiotic bacteria lead to increased antiviral response against vesicular stomatitis virus. Antivir Res 75: 266-274.

6. Marques A, Lourenço HM, Nunes ML, Cristina R, Carlos S, et al. (2011) New tools to assess toxicity, bioaccessibility and uptake of chemical contaminants in meat and seafood. Food Res Int 44: 510-522.
7. Trapecar M, Leouffre T, Faure M, Henrik EJ, Per EG, et al. (2011) The use of a porcine intestinal cell model system for evaluating the food safety risk of Bacillus cereus probiotics and the implications for assessing enterotoxigenicity. APMIS 119: 877-884.

8. Cencič, A, Lefèvre, F, Koren S, Bonnardière LC (1999) Tetracycline-controlled expression of glycosylated porcine interferon-gamma in mammalian cells. Anim Biotechnol 10: 1-2.

9. Cencič A, Hennry C, Huet JC, Koren S, Lefevre F, La Bonnardiere, Claude. The porcine trophoblastic interferon-gamma, secreted by a polarized epithelium has specific structural and biochemical properties. Eur J Biochem 2002, letn. 269, št. 11, str. 2772-2781

10. Šikić P, Maja K, Anja SM, Sonja, Cencič, Avrelija (2010) Attachment, invasion, and translocation of Campylobacter jejuni in pig small-intestinal epithelial cells. Foodborne Pathogens and Disease 7: 589-595.

11. Klingberg DT, Pedersen HM, Cencič A, Bude BB (2005) Application of measurements of transepithelial electrical resistance of intestinal epithelial cell monolayers to evaluate probiotic activity. Appl Environ Microbiol 71: 7528 7530 .

12. Cencič, A, Jakobsen, Mogens. Functional cell model of non-tumorigenic intestinal ephithelial cells IPEC-J2 to study probiotic-pathogen-gut ephitelium interactions. $\mathrm{V}$ : Beyond antimicrobials-the future of gut microbiology, (Reproduction Nutrition Development, Supl. 1). Jouy-en-Josas (France): EDP Sciences, 2002, 2002, 42, supl. 1, s16.

13. Cencič, Jernej, Cencič, Avrelija. Applications of muscle cell assay. V: BIT's 7th Annual congress of International drug discovery science and technology, Shanghai, China, October 22-25, 2009 : Abstract book. Shanghai (China) International drug discovery science and technology, 2009, str. 599

14. Cencič, Jernej, Langerholc, Tomaž, Trapečar, Martin, Gradišnik, Lidija Cencič, Avrelija. Novel muscle cell assay for iapplications [i. e. applications] in biomedicine. V: Abstracts, (Current medicinal chemistry). Schiphol: Bentham Science Publishers, 2012, str. 135-136.

15. Trapečar, Martin, Gorenjak, Mario, Žbontar Zver, Lea, Cencič, Avrelija Untransformed functional 3D cell models of the gut : the new frontier for discovery and evaluation of oral medication and nutraceuticals. V: Abstracts, (Current medicinal chemistry). Schiphol: Bentham Science Publishers, 2012 str. 119.

16. Filipič BS, Srećko B, Tanja TS, Cencič A, Koren S (2007) Extracellular Ca++ ions affect the cytocidal and antiproliferative activity ofhuman interferon. $V$ The 4th International conference on tumor microenvironment: Progression, theraphy and prevention, Florence, Italy, March 6-10, 2007 : program and abstract. Florence: American association for cancer research. str. 70 . 